\title{
Corporate Goverance Determinants of Earnings Management: Evidence from Nigerian Quoted Companies
}

\author{
*Omoye, A.S (Ph.D) \\ Dept. of Accounting, University of Benin \\ Email: alade.omoye@uniben.edu \\ Prof. P.O. Eriki \\ Department of Banking and FinanceFaculty of Management Sciences, University of Benin, Nigeria \\ Email: peter.eriki@yahoo.com
}

Doi:10.5901/mjss.2014.v5n23p553

\section{Abstract}

The aim of this study was to classify Nigerian quoted companies into high and low earnings management levels and also to investigate how corporate governance mechanisms relate to these categories of earnings management levels. A sample of 130 companies were drawn from quoted companies on the Nigerian stock exchange over the period of 2005 to 2010 and to identify the unique firm's corporate governance characteristics and control variables that influence firms' decision to engage in earnings management, we conducted descriptive statistics, correlation matrix, diagnostic test and binary regressions analyses of the data. The study revealed that, quoted companies in Nigeria prefer to use high earnings management practices; Board independence had a positive and significant influence on the probability of Nigerian companies adopting absolute high earnings management, Audit committee independence had a negative and significant influence on the probability of Nigerian companies adopting absolute high earnings management, Board gender representation had a negative and significant influence on the probability of Nigerian firms adopting absolute high earnings management and Also Board size and CEO shareholding were found to be statistically not significant in influencing the likelihood of Nigerian quoted companies adopting high earnings management levels. The control variables; firm size, auditors type and industry class were found to be positive and statistically significant in determining absolute high earnings management levels of Nigeria quoted companies.. This study recommended that stakeholders in quoted companies in Nigeria should promote sound audit independence, intensify the independence of board composition and encourage more female representation on the board.

Keywords: corporate governance, earnings management, board size, board independence,

\section{Introduction}

Earnings management is recognized as attempts by management to influence or manipulate reported earnings by using specific accounting methods or accelerating expense or revenue transactions, or using other methods designed to influence short-term earnings. The term as generally understood refers to systematic misrepresentation of the true income and assets of corporations or other organizations. Earnings management occurs when managers use judgment in financial reporting in structuring transactions to alter financial reports, to either mislead some stakeholders about the underlying economic performance of the company, or to influence contractual outcomes that depend on reported accounting.

The effect of corporate governance on earnings management has stimulated research attention. However, from the preview of prior studies, we identified the following issues. Firstly, it appears that there is no general agreement regarding the effect of corporate governance variables on earnings management. Secondly, there is also limited research on earnings management classification of Nigerian quoted companies. Thirdly, the researcher is unaware of any study in the Nigerian corporate environment that has classified Nigerian quoted companies in high and high positive earnings management categories and to also examine how corporate governance variables relate to these firms earnings management categories. Chtourou, Bedard and Courteau (2001) identified that classification of companies earnings management makes the grouping of companies into high-positive or negative earnings management group possible and also allows researchers to investigate determinant of firm's choice of different levels of earnings management strategy. In the context of Nigeria, some attempts have equally been made over the years to study earnings management and 
corporate governance of Nigerian quoted companies empirically and this include the works of Adenikinju and Ayorinde (2001) that focuses on Nigerian quoted companies corporate governance performance, Olayinka,(2012) which use questionnaire to examine some corporate governance mechanism and earnings management relationship in Nigeria, Dabor \& Adeyemi (2009) that examine corporate governance and the credibility of financial reports and Isenmila \& Afensimi (2012) that examine the relationship between earnings management and ownership structure of Nigerian quoted banks. However, these Nigerian studies made no attempt to classify Nigerian quoted companies into different levels or extent of earnings management and also did not investigated how corporate governance relates to the probability of Nigerian quoted associated with high or low earnings management. It is in the light of these inadequacies that this study's contribution provides the relevance.

Arising from our research problems above are the following specific research questions:

1. How is board size related to high earnings management levels of Nigerian quoted companies?

2. What impact does board independence have on high earnings management levels of Nigerian quoted companies?

3. How does audit committee independence relates to high earnings management levels of Nigerian quoted companies?

4. What is the influence of CEO shareholding on high earnings management levels of Nigerian quoted companies?

5. How is board gender representation related to high earnings management levels of Nigerian quoted companies?

\section{Literature Review}

The literature on corporate governance provides mounting evidence on how governance structures are associated earning quality/management practices. The discussion below focus on literature that relates to major corporate governance indicators such as board size, board independence, board gender balance, CEO status, and audit committee independence to earnings management levels.

\subsection{Board Size and Earnings Management}

There has been increasing attention in the accounting literature about the role of the board of directors bothering on earnings management and financial reporting. Beasley (1996) ascertain that attention springs from the board of director's responsibility to monitor the quality of financial reporting in a firm. It's the duty of board of directors to ensure that the organization is taking full advantage of the opportunities and that market value of the firm is increasing. A board can be effective if its decision power and influence on the managers is very strong.

Board size is value-relevant measurement of board operations and in instituting well designed corporate governance in firms. The size of the Board is fundamental in both small and large firms in ensuring good corporate governance practices as this relate to earning management practices. According to Jensen (1993) process losses increase as board size grows because larger boards obstruct the free flow and effective exchange of ideas between corporate directors. Besides, Eisenberg, Sundgren and Wells (1998) indicate the possibility that coalition costs among board members increase as board size rises, thereby facilitating the CEO's dominance over other board members. Yermack (1996) stresses that as board size grows, there is tendency that process losses and combination costs overshadow the benefit of having input by more directors. In line with this notion, Yermack (1996) shows that firms with smaller boards are valued more highly by the market, a result that holds through numerous sensitivity checks, estimation techniques, and several additional controls. Ahmadu, Tukur and Aminu (2011) also stress that board size is a significant board attribute and affects board functions and eventually corporate governance performance. Lipton and Lorsch (1992) and Jensen (1993) assert that large boards could be less effective than small boards. Increase in board's size occurs with increase in agency problems (such as director free-riding) within the board and the board becomes less effective. Jensen (1993) further notes that the decision-making power of the board becomes slower as a result of the introduction of more people into the board and such can influence firm accounting choice decision and earning management practices. Owing to the various views and lack of consensus, we assume that the relationship between earnings management practices and size of the board are mixed related. 


\subsection{Board composition, Independence and Earnings Management}

In the past, empirical evidence on the efficacy of the monitoring that outsiders provide appears to depend on the setting in which it is examined. Also there have been considerable studies supporting that outside directors protect shareholders in specific instances when there is an agency problem (Brickley \& James, 1987; Weisbach, 1988; Byrd \& Hickman, 1992; and Lee, Rosenstein, Rangan, \& Davidson, 1992). According to Bhagat \& Black (2000), the relation between the proportion of outside directors and long-term financial performance, however, has not been supported in empirical research.

Consistent with the recommendation of the Blue Ribbon Panel, we also expect that the background of these independent outside directors may be an important determinant of their monitoring effectiveness (Indejikian, 2007). To further advance the argument, Adetunji \& Olawuyi (2009), support the notion that a director with a corporate or financial background may be more familiar with the ways that earnings can be managed and may better understand the implications of earnings manipulation. From the various perspectives, we expect a negative associative between the proportion of independent directors on the board and the level of earnings management. Dabor and Adeyemi (2009) find out that including non-executive directors on the board are likely to enhance the credibility of financial statements and recommend the use of non-executive board as a variable for checking the credibility of financial reports or earnings management.

Following the above, we therefore assume in this study that a large proportion of the independent outside board members would promote independence and reduce cases of earnings management.

\subsection{Board Gender and Earnings Management}

There is a growing literature showing (1) an increasing trend of earnings management (2) that good corporate governance including more independent boards can constrain earnings management and (3) that the presence of women directors is likely to improve board monitoring and governance, thereby reducing earnings management (Clikeman, Geiger \& O'Connell 2001). Scott (2009) examines the association between female board directorship and earnings management/accruals quality flows from two factors. Scott (2009) finds that the majority of firms across most industries in US for the period of the study have female directors and, yet, despite the presence of such a large number of female directors, no study has examined (or for that matter considered) the role of female directors in earnings management. Corporate boards with female directors (and female non-executive directors) are more likely to be able to improve board monitoring and hence constrain earnings management. Based on the growing literature which shows that women (i) employ a more democratic, transformational and trust-building leadership style (Klenke 2003; Trinidad \& Normore 2005), (ii) exhibit greater risk aversion in financial decision-making settings (Riley \& Chow 1992; Powell \& Ansic 1997; Hinz, McCarthy \& Turner, 1997; Surette 1998) and (iii) exhibit higher ethical standards on their decisions than their male counterparts (Clikeman et al. 2001).

Following the above, one may be concluding that the inclusion of more female directors in the board of companies will have a negative relationship with earnings management.

\subsection{Audit Committee Independence and Earnings Management}

A number of empirical studies have examined the relationship between audit committee independence and earnings management. Klein (2002) which analyses the relation between audit committee and board characteristics and earnings management using a two year sample of 500 firms, finds that independent audit committees significantly reduced abnormal accruals as did an independent boards. Reductions in audit committee independence are accompanied by large increases in abnormal accruals. The effect is most pronounced when the board or the resultant audit committee is comprised of a minority of outside directors i.e., when audit committee changes from majority to minority of independent directors. Carcello, Hermanson, Neal \& Riley (2002) use a sample of 100 Fortune 500 companies to examine if a more independent audit committee tries to protect its reputation by insisting on differentially higher audit quality.

In the context of Nigeria, Olayinka (2012) and Dabor and Adeyemi (2009) also observe that independent audit committee with members that possess certain level of financial competencies would reduce the likelihood of earnings management. They recommended that Audit committee members be independent and should be encouraged to possess a certain level of financial competencies in order to decrease the likelihood of earnings management.

Following the above, we concluded that the audit committee independence will have a negative relationship with earnings management. 


\section{Ceo Shareholding and Earnings Management}

The scale of the modern corporation makes the separation of ownership and control common, especially at the largest firms, Jensen, \& Meckling, (2009). Dispersed investor owners rely on professional managers, who rarely own more than a tiny fraction of the companies they manage, to make investment and payout decisions. A manager whose personal financial stake is unaffected by the value of the company she manages may act in ways that, while privately beneficial, reduce the value of her investors' claims. This separation of ownership and control has long been recognized as a root of corporate governance problems.

Partly because of concerns that managers' insulation from their companies' performance led to value-destroying executive behavior, during the 1990s executives became much more directly exposed to changes in their companies' share prices. This increase in exposure came through substantial grants of options and stock, DuCharme, Malatesta, \& Sefcik (2004). By the end of the decade, managers' potential incentives to affect the share prices of their companies had increased dramatically. These changes were motivated by a desire to align managers' incentives with those of shareholders, but research shows that they may have brought a new set of problems. According to Bergstresser, \& Philippon, (2012), management incentives to the stock price may have had the perverse effect of encouraging managers to exploit their discretion in reporting earnings, with an eye to manipulating the stock prices of their companies evidence shows about the incentivized of CEOs of those whose overall compensation is more sensitive to company share prices lead companies with higher levels of earnings management. We go on to document that periods of high accruals coincide with unusually large option exercise by CEOs and significant unloading of shares by CEOs and other top executives.

If the insulated CEO, undertaking socially wasteful but personally beneficial projects, was an archetype of the 1970s and 1980s, then a highly incentivized CEO, according to Erickson, Hanlon, \& Maydew, (2006), manipulating reported earnings, may have become an archetype of the late 1990s Hermalin, (2005). This does not mean that financial incentives destroy value on average, but it does mean that making the most efficient use of high powered incentives requires careful consideration of the their possible good and ill effects Ewert, \& Wagenhofer, (2005). In particular, highpowered incentives based on stock price performance seem likely to work best when coupled with a careful consideration of managers' opportunities to exploit these incentives through the discretion that they enjoy in reporting their firms' performance.

\section{Data and Methodology}

The population consisted of all companies quoted on the Nigeria Stock Exchange as at December 31, 2011. There were 250 securities listed on the Exchange, made up of 36 Government stocks, 12 corporate bonds, 3 Debenture/Preference stocks, 198 Equity/Ordinary shares of companies and 1 exchange traded fund (NSE, Factbook 2011). It should be noted that each company in the population must have finished its obligation in delivering annual report for the year ended 2005 to 2010 while the final sample size for this study was based on Yamane's formula (1967) in Guilford \& Fruchter (1973). The statistical formula is stated, thus:

$$
n=\frac{N}{1+N\left(e^{2}\right)}
$$

Where:

$\mathrm{n}=$ sample size

$\mathrm{N}=$ Population size

$\mathrm{e}=$ Level of significance desired

given that:

$\mathrm{e}=0.05$ and $\mathrm{N}=198$

$\mathrm{n}=198$

$1+198(0.05)^{2}$

Which is 132

Following the above formula, the minimum sample size for this study is 132 quoted companies at $5 \%$ levels but will choose to use 130 companies due to non availability of data. In this study the random sampling technique was adopted and our sampling technique was adjusted to ensure fair representativeness from each sector in the sample size. The companies in this study were drawn from the 198 equity companies listed on the Nigeria stock exchange, comprising the following sectors: Banking, Insurance, Agriculture, Automobile \& Tyre, Breweries, Building Materials, Chemical and Paints. Others are Conglomerates companies, Food/Beverages \& Tobacco, Footwear, Healthcare, Industrial/Domestic Products, Packaging, Printing \& Publishing, Textiles and petroleum. 
In this study we used secondary data and this data were sourced from the annual reports of the selected companies and Nigerian Stock Exchange (NSE) factbook. The balance sheet, income statement and cash flow statement from the quoted companies' annual reports provided all the information as regards the computing of earnings management and firm size (Asset) while the NSE factbook and other aspect of the selected companies annual report were subjected to content analysis to identify data on board independence, Board Gender Representation, Board Size, auditor type, audit committee independence, CEO shareholding and Firm Industry group.

Following the literature and theoretical framework of this study, our models focused on identifying corporate governance indicators that are statistically significant in determining the probability of firms engaging in high earnings management levels in Nigeria.

Before we specify the models for this study, first we provide some clarification on the measurement of earnings management. In accounting, accruals have been used as the proxy for earnings management practices. These accruals can be measured by two different approaches. These includes (1) Balance sheet approach and (2) Cash flow statement approach

(A) Balance Sheet Approach

According to Healey (1985) and Jones (1991), this approach of total accruals (TA) measure can be calculated by using the following formula.

$\mathrm{TA}=\Delta \mathrm{CA}-\Delta \mathrm{Cash}-\Delta \mathrm{CL}+\Delta \mathrm{DCL}-\mathrm{DEP}$

Where:

$\mathrm{TA}=$ total accruals

$\triangle C A$ is change in current assets in year $t$

$\triangle$ Cash is the change in cash and cash equivalents in year $t$

$\triangle \mathrm{CL}$ is the change in current liabilities in year $\mathrm{t}$

$\triangle D C L$ is the change in debt included in the current liabilities in year $t$

DEP is depreciation and amortization expense in year $t$

(B) Cash Flows Statement Approach

Accruals can also be calculated by the approach presented in equation (3.3) which can be caculated as follows:

$T A=N . I-C F O$.

Where: TA is total accruals in year $t$

$\mathrm{N} . \mathrm{I}$ is Net Income in year $\mathrm{t}$

CFO is cash flows from operating activities in year $t$

In weighing both approaches, we found that most researchers prefer cash flows approach than the balance sheet approach. Collins \& Hriber (1999) argue that using balance sheet approach to compute total accruals is inferior in some circumstances to a cash flow statement based approach. However, Bartov, Gul and Tsui (2000) use balance sheet approach, but they pointed out that the reason for using balance sheet approach is that data regarding cash flows from operations was not available over the entire period of estimation.

In the view of researchers total accruals are not actually a measure of earnings management. Earnings management can only be obtained when discretion for these accruals is conducted. Accrual has been divided in two parts, that is; discretionary accruals and non discretionary accruals. After calculating total accruals, non-discretionary accruals are subtracted from total accruals to get discretionary accruals. Many methods have been used by researchers in order to calculate the discretionary accruals like DeAngelo Model (1986), Healy Model (1985), Jones Model (1991) and the latest Modified Jones Model (1995).

According to Modified Jones Model (1995), discretionary accruals are calculated by deducting non-discretionary accruals from total accruals as shown in equation 3.4 and 3.5. Accrual rises when there is a discrepancy between the timing of cash flows and the timing of the accounting recognition of revenues. Although at the end, total accrual would naturally become zero, it could not be eliminated in most cases, to tell what non-discretionary accruals are, which is within the normal range, and what discretionary accruals are, which is suspicious in managing earnings. The total accruals when deflated by total assets as represented in equation 3. 4 and 3.5 below and the computed deflated total accruals which when deducted from the fitted deflated total accruals yield non-discretionary accruals which proxy earnings management

$$
\frac{T A_{i, t}}{T A_{i, t,-1}}=\beta_{0}+\beta_{1}\left(\frac{\Delta \operatorname{Rev} v}{T A_{i, t,-1}}-\frac{\Delta A \operatorname{Re} c_{i, t}}{T A_{i, t,-1}}\right)+\beta_{2}\left(\frac{P P E_{i, t}}{T A_{i, t,-1}}\right)+\varepsilon_{i t}
$$

Where, ${ }^{T A_{c i, t}}=$ Total Accruals, calculated as firm i's income before extraordinary items and discontinued operations, minus cash flows from continuing operations plus extraordinary items and discontinued operations in year $\mathrm{t}$; 
$T A_{s i, t-1}=$ Total Assets for firm i in year $\mathrm{t}-1$;

$\Delta \operatorname{Re} v=$ Change in net revenue (earnings) for firm i from year $\mathrm{t}-1$ to $\mathrm{t}$;

$\triangle A \operatorname{Re} c_{i, t}=$ Change in accounts receivable (debtors) for firm i from year $\mathrm{t}-1$ to $\mathrm{t}$;

$P P E_{i, t}=$ Gross property plant and equipment;

$E A R N Q_{i t}^{D A}=\mathcal{E}_{i, t}=\left|\frac{T A_{c i, t}}{T A_{s i, t-1}}-\frac{T \hat{A}_{c i, t}}{T A_{s i, t-1}}\right|$

$E A R N Q_{i t}^{D A}=$ earnings management level proxy by absolute discretionary accrual scaled by total assets. The

$E A R N Q_{i t}^{D A}$ value can assume positive or negative values and can be classified into High and Low levels based on a median value.In this study, we used the Modified Jones Model (1995), because it provide an earnings management measurement approach that provides a uniform and standard formula for computing discretionary and non-discretionary accruals for both non-financial and financial firms without consideration of firms industry specifics.

In the light of the above, earnings management for this study was computed based on the modified Jones model while the computed earnings management values were classified into high and low bracket using the median value of the observed quoted companies as a benchmark. The classifications of the selected companies into high and low earnings management categories necessitated our using binary regression models. The models allowed us to find out if corporate governance variables are statistically significant in influencing Nigerian quoted companies' decision to engage in High or low earnings management activities. A representation of the models is specified as follows;

$E A R N Q_{i t}^{D A}=\alpha_{i}+\propto_{1} B O A D S_{\mathrm{it}}+\propto_{2} B O A D I_{\mathrm{it}}+\propto_{3} B O A D G_{\mathrm{it}}+\propto_{4} C E O S_{\mathrm{it}}$

$+\propto_{5} A U D C I_{\mathrm{it}}+\propto_{6} S I Z E_{\mathrm{it}}+\propto_{7} I N D T Y E_{\mathrm{it}}+\propto_{8} A U D T Y P E_{\mathrm{it}}+\varepsilon_{i t}$

Where;

Dependent Variables:

$E A R N Q_{i t}^{D A}=$ Earnings management levels (absolute High (1) or low (0) )

Independent Variables:

BOARDS = Board Size

$\mathrm{BOADI}=$ Board Independence

BOADG $=$ Board Gender representation

CEOS = CEO Shareholding

$\mathrm{AUDCl}=$ Audit committee independence

SIZE $=$ Firm size

INDTYE= firm industry type or group

AUDTYPE $=$ firm Auditor type

$\varepsilon_{i t}=$ error terms

The apriori signs are;

$\alpha_{1}>0, \alpha_{2}>0, \alpha_{3}>0, \alpha_{4}<0, \alpha_{5}<0, \alpha_{6}<0, \alpha_{7}<0, \alpha_{8}<0$

In estimating the models and analyzing our data, a statistical method known as binary regression was adopted. The choice of binary regression models (probit, logit and extreme regression) is to relate the explanatory variables to the probability of a firm's engagement in earnings management was based on the limited nature of the dependent variable and the inability of the OLS multiple regression model to yield reliable coefficients and inference statistics in situation where the dependent variable is binary $(0$ and 1$)$. The binary regression models unlike others is based on the use of dichotonomous dependent variable, in which an observation scores one, if it is present and zero otherwise. This study did not use the ordered logit nor multinomial logistic regression since the ordered is used when the dependent variable is ranked and the multinomial is used for nominal dependent variables (Greene, 2003).

This study adopted the three widely used binary regression models (Logit, Probit and extreme). The difference in these models is based on the type of probability distribution they assumed. Logistic binary regression follows a cumulative logistic probability distribution, binary probit assumes cumulative normal distribution while the binary extreme assumes geometric distribution. Binary regressions method comes from statistics whose objective is to obtain a functional relationship between a transformed qualitative variable called logit, probit or extreme and the predictor variables which can be either quantitative or qualitative.

Added to the above, the use of binary regression methodology in this study was based on the following fundamental justifications (1) dependent variables for this study were binary in nature, that is they are restricted to 
"1"(Firms with high earnings management practices) and "0"( Firms with low earnings management practices). (2) The Binary regression is based on the use of Maximum likelihood Estimator (MLE) and when compared to the OLS data estimation techniques, it does not assume linearity, normality distribution, heteroscedaticity and hence in general has less stringent assumptions (Greene, 2003).

The preliminary statistical test to complement our data analyes techniques included descriptive statistics and correlation matrix. The data description, correlation matrix and binary regression models were estimated using Eviews 7.1 software.

\section{Discussion of Results}

The classification of the quoted companies used in this study was based on the observation median value. The highpositive earnings management companies are quoted companies with values that exceeded the overall observation median positive value (0.488) while the high- negative earnings management companies are quoted companies that exceeded the overall observation median negative value $(-0.206)$.

Table 4.1 below represents the descriptive statistic of the selected quoted companies that fall under the absolute High-Low earnings management category. This means that the companies' descriptive statistics in table 4.1 shows the summary of Nigerian quoted companies that adopt high-low positive and negative earnings management strategy.

Table 4.1: Descriptive Statistics for Absolute High-Low earnings management companies

\begin{tabular}{|l|c|c|c|}
\hline Variables & Mean & Std.Dev & Jarque-Bera \\
\hline EARNS & 0.47 & 0.49 & $88.00(0.0)^{\star}$ \\
SIZE & 212 & 3972 & $5639166(0.0)^{\star}$ \\
INDTYPE & 0.27 & 0.44 & $109.02(0.0)^{\star}$ \\
BOARDS & 9.67 & 2.92 & $89.00(0.0)^{\star}$ \\
BOARDI & 0.84 & 3.58 & $5991902(0.0)^{\star}$ \\
BOARDG & 0.08 & 0.11 & $642.51(0.0)^{\star}$ \\
AUDTYPPE & 0.64 & 0.47 & $91.40(0.0)^{*}$ \\
AUDCI & 0.52 & 0.13 & $162.76(0.0)^{\star}$ \\
\hline
\end{tabular}

Source: Source: (Author's computation, 2014)

Table 4.1, shows the mean (average) for each of the variables, their standard deviation (degree of dispersion) and Jarque-Bera (JB) statistics (normality test) for both companies that practice High-Low positive and High-Low negative earnings management. The results on table 4.1, provided some insight into the nature of the selected companies that were used in this study. Firstly, the large standard deviation of SIZE (log of asset) shows that the sampled companies are not dominated by either large or small companies. That is the companies are relatively equal in size. Secondly, it was also observed that about $47 \%$ of the sampled companies adopted high positive or negative earnings management while about $53 \%$ practices low negative or positive earnings management. This high value in a country like Nigeria where stakeholder are interested in companies that produce quality financial reports, clearly shows that there is high earnings management among Nigeria quoted companies. Third, it was also found out that; about $27 \%$ of the firms selected is grouped under financial industry, about $84 \%$ had board independence, about $8 \%$ of the selected firms has boards with female presence, about $52 \%$ had audit committee that are independent and about $64 \%$ of the firms selected were audited by the Big-4(KPMG, PWC, AKINTOLA WILLIAMS \& DELIOTTE and ERNEST \& YOUNG). The results above also showed that the average board size for our sampled companies is about ten (10) board members. Lastly, the JarqueBera(JB) statistics in table 4.1 showed that most of the variables are normally distributed at $1 \%$ levels of significance. This therefore means that there is no outlier in the data that would impair the generalization from this study.

In estimating and analysing the relationship between corporate governance and absolute high earnings management, the three binary regression models (Logit, Probit and extreme) were estimated and presented (See Table 4.2) below. The results from these three binary regression models are presented and discussed as follows; 
Table 4.2: EARN (Absolute High-Low Earnings Management) Binary regression results

\begin{tabular}{|c|c|c|c|c|}
\hline & $\begin{array}{l}\text { Expected } \\
\text { Sign }\end{array}$ & $\begin{array}{l}\text { EARN Model } \\
\text { (Binary Logit) }\end{array}$ & $\begin{array}{l}\text { EARN Model } \\
\text { (Binary Probit) }\end{array}$ & $\begin{array}{c}\text { EARN Model } \\
\text { (Binary Extreme) }\end{array}$ \\
\hline C & & $\begin{array}{c}1.57 \\
(3.0)^{\star} \\
(0.002)\end{array}$ & $\begin{array}{c}0.98 \\
(3.1)^{\star} \\
(0.001)\end{array}$ & $\begin{array}{c}1.57 \\
(4.4)^{\star} \\
(0.00)^{\star}\end{array}$ \\
\hline SIZE & + & $\begin{array}{c}3.56 \mathrm{E}-05 \\
(2.4)^{\star} \\
(0.013)^{\star}\end{array}$ & $\begin{array}{c}2.25 \mathrm{E}-06 \\
(2.6)^{\star} \\
(0.007)\end{array}$ & $\begin{array}{c}7.31 \mathrm{E}-05 \\
(0.3) \\
(0.00)\end{array}$ \\
\hline INDTYPE & + & $\begin{array}{c}0.38 \\
(1.7)^{\star} \\
(0.075)^{\star}\end{array}$ & $\begin{array}{c}0.23 \\
(1.7)^{\star} \\
(0.072)\end{array}$ & $\begin{array}{c}0.38 \\
(2.3)^{\star} \\
(0.016)^{\star}\end{array}$ \\
\hline CEOS & + & $\begin{array}{c}-4.08 \mathrm{E}-05 \\
(-0.1) \\
(0.85)\end{array}$ & $\begin{array}{c}-2.44 \mathrm{E}-12 \\
(-0.1) \\
(0.85)\end{array}$ & $\begin{array}{c}2.30 \mathrm{E}-12 \\
(0.1) \\
(0.859)\end{array}$ \\
\hline BOARDS & - & $\begin{array}{l}-0.05 \\
(-1.5) \\
(0.11)\end{array}$ & $\begin{array}{c}-0.03 \\
(-1.6)^{\star} \\
(0.106)\end{array}$ & $\begin{array}{c}-0.01 \\
(-0.6) \\
(0.538)\end{array}$ \\
\hline BOARDI & - & $\begin{array}{c}0.02 \\
(2.0)^{\star} \\
(0.036)\end{array}$ & $\begin{array}{c}0.01 \\
(2.2)^{\star} \\
(0.02)^{\star}\end{array}$ & $\begin{array}{c}0.03 \\
(2.2)^{\star} \\
(0.013)^{\star}\end{array}$ \\
\hline BOARDG & - & $\begin{array}{c}-1.88 \\
(-2.1)^{*} \\
(0.03)\end{array}$ & $\begin{array}{c}-1.17 \\
(-2.2)^{\star} \\
(0.024)\end{array}$ & $\begin{array}{l}-1.88 \\
(-3.5)^{*} \\
(0.00)\end{array}$ \\
\hline AUDTYPPE & & $\begin{array}{c}0.28 \\
(1.4) \\
(0.134)\end{array}$ & $\begin{array}{c}0.17 \\
(1.5) \\
(0.13)\end{array}$ & $\begin{array}{l}0.28 \\
(2.1)^{\star} \\
(0.02)\end{array}$ \\
\hline AUDCI & & $\begin{array}{c}-2.55 \\
(-3.5)^{\star} \\
(0.00)\end{array}$ & $\begin{array}{c}-1.59 \\
(-3.6)^{*} \\
(0.00)^{*}\end{array}$ & $\begin{array}{l}-2.55 \\
(-5.0)^{\star} \\
(0.00)^{\star}\end{array}$ \\
\hline McFadden R-Squared & & 0.53 & 0.53 & 0.51 \\
\hline LR Statistics (9 df) & & $23.5(0.0)$ & $23.4(0.0)$ & $11.2(0.0)$ \\
\hline Log Likelihood (LL) & & -353.4 & -353.5 & -359.6 \\
\hline Probability distribution & & Logistic & Normal & Geometric \\
\hline & & 528 & 528 & 528 \\
\hline Obs with Dep = 0 & & 278 & 278 & 278 \\
\hline Obs with Dep = 1 & & 250 & 250 & 250 \\
\hline
\end{tabular}

Note: (1) Parentheses ( ) are Z-statistic (2) * $5 \%$ level of significance respective

The co-efficient, z-values and p-values respectively are reported in parentheses.

In table 4.12, we observed that all three binary models provided relatively similar results, in terms of their signs (relationship). This therefore means that all three binary regressions provide relevant details for explaining firms' decision to adopt High earnings management practices. In trying to select from the three models the Log Likelihood (LL) is adopted. The consensus is that the higher the value of $L L$, the better the results. The value of the log likelihood function (LL) was marginally higher in EARNS extreme binary model (-359.6), suggesting that it was relatively superior to EARNS3 Binary logistic Model (-353.3) and EARNS Binary Probit Model (-353.4). Other model selection techniques were not considered. The Akaike Information Criterion (AIC) was not use to control for parameters, while comparing the goodness-of-fits for these models since they all have the same number of parameters. The Bayesian Information Criterion (BIC) was also not used to control for the number of observations since all three models adopted same sampled companies and observations. The Binary classification of these models was well representative since about 250 observations were classified under High earnings management category (1) while 278 was classified as low earnings management category (0). This means that both categories were well represented in that data that was used for our analysis.

Added to the above, the McFadden R-squared value from the three binary regression results shows that about 53 percent of the outcome of the dependent variable (EARNS) is predicted jointly by all the independent variables. LR statistic for all three models revealed that they were all statistically significant at $5 \%$ levels and valid in explaining the 
outcome of the dependent variable. The reported results of all three binary regression models were based on Maximum Likelihood Huber/White Heteroskedasticity-consistent standard errors and covariance. This means that the three binary regression results reported are free from Heteroskedasticity problem which is commonly associated with data from companies with different characteristics. It should be noted that all three binary regression models provided similar results therefore we relied upon all the three binary regression results. The results obtained are discussed as follows;

Board Size (BOARDS) appears to be statistically insignificant at $5 \%$ and was also negatively associated with the probability of firm's to adopt high earnings management strategy. This result to the acceptance of Hypothesis ( $\mathrm{H} 1)$, which suggests that firm's board size and high level of earnings management are significantly related. This means that large board is not negatively related to high earnings management strategy but not significantly. The statistical insignificance of board size at $5 \%$ levels indicates that board size as a corporate governance variable is not significant in understanding the motivation of Nigerian quoted companies adoption of high earnings management strategy. The insignificant negative relationship between high earnings management strategy and board size is in consonance with the findings of Abbott , Parker and Peters (2004) that there is no significant relationship between the two variables;

Board Independence (BOARDI) was found to be statistically significant at $5 \%$ levels and was positively associated with the probability of quoted firm's that engage in high earnings management practices in Nigeria.We accepts hypothesis $(\mathrm{H} 2)$, which suggests the levels of earnings management and board independence should be statistically significant. Although the positive relationship was unexpected, as we expected that firms' board independence should be negatively associated to high levels of earnings management. The justification for this might be due to the motivation of independent board to positively encourage high earnings strategy to allow them smooth firm's profitability and same time to maintain a steady director compensation for themselves. This finding is inconsistent with other studies such as Dechow, Sloan \& Sweary (1996), Ball, Kothari and Robin (2000), Agrawal \& Chadha (2005), Ashbough, Collins \& Lafond (2006)that independent board will reduce the likelihood of firm's engagement in earnings management but provide new insight into Nigerian corporate governance literature. This finding in summary implies that most independent board of Nigerian quoted companies significantly encourages firms to adopt high levels of earnings management practices;

Auditor committee independence (AUDCI) was also found to be statistically significant at $5 \%$ levels and was negatively associated with the probability of firm's choice of high earnings management practices. This means that quoted Nigerian companies with more independent audit committee are less likely to be subjected to high earnings management. This in other word implies that audit committee independence significantly decreases the likelihoods of firm's engagement in high earnings management. This result necessitate our acceptance of hypothesis $(\mathrm{H} 3)$, which suggests that firms audit committee independence and earnings management levels should have a significant relationship and also conform to apriori expectation. This study like similar ones (westphal and Zajac 1997, Dezoort and Salterio 2001) confirms that independence of audit committee as a variable of corporate governance is relevant in checking high earnings management practice among Nigerian quoted companies. The results of high -positive and highnegative earnings management also shows that audit committee independence is also statistically significant in influencing both over and under reporting of earnings among Nigerian quoted companies;

CEO Shareholding (CEOS) like in the case of both high-negative and high positive earnings management results also appeared to be negative and statistically insignificant in determining quoted Nigerian firm's decision to engage in high level of earnings management. This implies that we should reject Hypothesis $\mathrm{H} 4$, which indicates that CEO shareholding and earnings management levels are significantly related. The statistically insignificant values of this variable from all binary regression results suggest that firms with CEOs that own shares are not likely to engage in high earnings management practices (ceteris paribus) while the negative coefficient indicates that CEOs holding shares in companies would not significantly prefer high level of earnings management but the High-positive earnings management results shows that companies with CEO owing shares are more likely to adopt high earnings management strategy but the decision to choose this option is insignificant;

Board Gender (BOARDG) appears to be statistically significant at $5 \%$ levels. The variable was negatively associated with the probability of firm's engagement in high earnings management practices. This means that Nigerian quoted companies with female board members are more likely to have infrequent cases of high earnings management. This finding conforms to apriori expectation, that more female in firm's board discourage high earnings management practices. This finding is in line with the work of Riley and Chow (1992), Powell and Ansic (1997), Hinz, McCarthy and Turner (1997), and Clikeman et al (2001) that show that board gender is relevant in reducing fraud and earnings management and the reasons for this might be (1) Female board members have greater risk aversion in financial decision-making settings and (2) Female board members have higher ethical standards on their decisions than their male counterparts. This provide evidence for ours to accept Hypothesis (H2), which suggests that firms board gender representation and earnings management levels should significantly be related. This finding when compared to the high- 
negative and high-positive earnings management results shows that female board representation not only significantly discourage high earnings management, but also often favour income decreasing management strategy significantly (High-negative earnings management) than income increasing management strategy;

Firm Auditors Type (AUDTYPPE) appears to be inconsistent with apriori expectation and was statistically significant in influencing firm's decision to practice high earnings management strategy. The results in other word implies that the use of quality audit firm by Nigerian quoted firms such as the Big 4 audit firms would increased the likelihood of Firm engagement in high earnings management practices. This also implies that External Audit firms encourage high earnings management practices among Nigeria quoted companies. This finding is inconsistent with the views of Becker et al (1998), Francis et al (1999) that companies using Big auditor's report lower levels of discretionary accruals than firms employing non-Big auditors;

Firm size (SIZE) was also found to be positive and statistically significant in influencing firm's decision to practice high earnings management. This means that firm size is positively related to high earnings management. This finding supports the views that large firms are more likely to manage earnings than small firms (Bartan \& Simko, 2002, and Myers \& Skinner, 2000). The positive association between high earnings management and firm size implies that Big Nigeria quoted companies often engage in high earnings management and this might be attributed to their desire to smooth earnings over the years and also to pay less amount of tax; and

Industry Type dummy (INDTYPE) unlike our high-positive and high-negative earnings management results, appears to be positive and statistically significant in influencing firm's decision to practice high earnings management strategy. On the basis of our classification of industry in this study, it implies that firms in financial industry are more likely to be positively associated with high earnings management than non-financial industry in Nigeria. This finding is in consonance with the works of Teoh, Welch and Wong (1998) and Nelson, Elliot and Tarpley (2002) that identify some industries to engage more significantly in earnings than others.

\section{Conclusion}

This study has examined corporate governance variables and its influence on earnings management levels among selected Nigerian quoted companies using binary regression based models to find answers to the research questions as corporate governance and earnings management continue to remain an area of debate, any effort to improve understanding in this area may lead to better approach of financial reporting. Consequently, preventing high earnings management among Nigeria quoted companies through the implementation of corporate governance variables would yield optimal results if policy makers and other stakeholders in Nigeria would promote sound audit committee independence, intensify the independence of board composition and encourage more female representation in the board of Nigerian quoted companies. By this, agency problem could be mitigated and there would be improved users reliance on corporate financial reports for decision making.

On the basis of all our results we summarize our findings as follows; firstly, quoted firms in Nigeria prefer to adopt high-negative earnings management than high-positive earnings management levels; secondary, board Size as corporate governance variable is statistically not significant in influencing the likelihood of Nigerian quoted firm adopting neither high positive nor high negative earnings management levels; thirdly, board independence had a positive and significant influence on the probability of Nigerian firms adopting absolute high earnings management and high positive earnings management strategy but was negatively and statistically insignificant in influencing firm's decision to practice highpositive earnings management levels; fourthly, audit committee independence had a negative and significant influence on the probability of Nigerian firms adopting absolute high earnings management, high positive earnings management and high-negative earnings management levels; fifthly, the units of shares held by CEO does not have significant influence on the likehood of Nigerian quoted firm adopting neither high positive nor high negative earnings management levels: and finally; board gender representation had a negative and significant influence on the probability of Nigerian firms adopting absolute high earnings management and high negative earnings management but was positively and statistically insignificant in influencing firms decision to practice high-positive earnings management levels.

\section{References}

Abbott, L., Parker S., \& Peters, G. (2004). Audit committee characteristicsand restatements. Auditing: A Journal of Practice and Theory, 23, $69-87$

Adenikinju, O., \& Ayorinde, F. (2001). Ownership structure, corporate governance and corporate performance: The case of Nigerian quoted companies, unpublished final report presented at the AERC biannual researchworkshop, Nairobi, Kenya. 
Adetunji, M.B., \& Olawoye, O. (2009). The effects of internal and external mechanism on governance and performance of corporate firms in nigeria. Journal of Corporate Ownership \& Control, 2(3) 1-7

Agrawal, A., \& Chadha, S. (2005). Corporate governance and accounting scandals. Journal of Law and Economics, 48 (2) $371-406$.

Ahmadu, U.S., Tukur, G., \& Aminu, S.M. (2011). Board independence and firm financial performance: Evidence from nigeria. Journal of African Research Consortium Nairobi, 1-24

Ashbaugh, H., Collins, D. W., \& LaFond, R. (2006). The effects of corporate governance on firms' credit ratings. Journal of Accounting \& Economics, $42(1 / 2)$ 203-243.

Ball, R., Kothari, S. P., \& Robin, A. (2000). The effect of international institutional factors on properties of accounting earnings. Journal of Accounting \& Economics 29 (1),1-51.

Barragato, C.A., \& Markelevich, A. (2008). Earnings quality following corporate acquisitions Managerial Finance, 34 (5), 304.

Barth, M., Landsman, W., \& Lang, M. (2008). International accounting standards and accounting quality. Journal of Accounting Research, 46, 467-498.

Barton, J., \& Simko, P. (2002). The balance sheet as an earnings management constraint. The Accounting Review, 7(4), 1-27.

Bartov, E., Gul. F.A \& Tsui, J. S. L.(2000). Descretionary-accuals model and audi qualifications. Journal of Accounting and Economics,30, (3) 243-460.

Beasley, M. (1996). An empirical analysis of the relation between the board of director composition and financial fraud. The Accounting Review, 71(4), 43-65.

Becker, C., Defond, M., Jiambalvo, J., \& Subramanyam, K. (1998). The effect of audit quality on earnings management, Contemporary Accounting Research, 15, 1-24.

Bedard, J. C., \& Johnstone, M. (2004). Earnings manipulation risk, corporate governance risk, and auditors planning and pricing decisions. The Accounting Review, 79 (2):277- 304

Bergstresser, D., \& Philippon, T. (2012). CEO incentives and earnings management, Journal of Financial Economics, 5(8), 145 - 157.

Bhagat, S., \& Black, B. (2000). Board independence and long-term performance. University of Colorado Working Paper.

Blue Ribbon Committee. (1999). Report and recommendations of the blue ribbon committee on improving the effectiveness of corporate audit committees. nyse and national association of securities dealers.

Brickley, J. A., \& James, C. M. (1987). The takeover market, corporate board composition, and ownership structure: The case of banking. Journal of law and economics, (30), 161-181.

Byrd, J., \& Hickman K. (1992). Do outside directors monitor managers? Evidence from tender offer bids. Journal of Financial Economics, $32,195-221$.

Cadbury, A. (1992). Report of the Committee on the Financial Aspects of Corporate Governance London: Gee Publishing.

Carcello, J.V., Hermanson D.R., Neal, T.L., \& Riley, R.A. (2002). Board chararacteristics and audit fees. Contemporary Accounting Research, 19,

Claessens, S., Djankov, S., \& Lang, L. H. P. (2000). The separation of ownership and control in East Asian corporations. Journal of Financial Economics, 58 (1-2), 81.

Clikean, P. M., Geiger, M. A., \& Connell, B. T. (2001). Student perceptions of earnings management, The effects of national origin and gender. Teaching Business Ethics, 5 (4) 389-410.

Collins, D., \& Hribar, P. (1999). Earnings-based and accruals-based market anomalities: One effect or two? Journal of Accounting and Economics, 29, 101-123

Companies and Allied Matters Act. (1990). Enacted by the federal government of nigeria.Corporations. Corporate Ownership and Control, 1, 20-30. CAMA (1991), sectine

Chtourou, S.M., Bedard, J., \& Courteau, L. (2001). Corporate governance and earnings management, online http://papers.ssrn. com/abstract $=275053$.

Dabor, E. L., \& Adeyemi, B. (2009). Corporate goverance and credibility of financial statements in nigeria. Journal of Business Systems, Governance and Ethics, 4(1), 13-34

Dechow, P., Sloan, R., \& Sweeny, A. (1996). Causes and consequences of earnings manipulation: An analysis of firms subject to enforcement actions by the SEC. Contemporary Accounting Research, 13 (1), 1-36. 3. 183-190.

Dechow, P.M., \& Skinner, D.J. (2000). Earnings management reconciling the views of accounting academics, practitioners, and regulators. Accounting Horizons, 14 (2), 235-250.

Dezoort, F.T. \& Salterio, E. S. (2001), The effect of corporate governance and financial reporting and audit knowledge on member committee members' judgement. Auditing: A Journal of Practice and Theory, 20,(2) 31-47

Drake. M.,Myers, J.N., \& Myers, L. A. (2009). Disclosure quality and the miss pricing of accruals and cash flow. Jounal of Accounting, Auditing and Finance, 24(3),357- 384

DuCharme, L., Malatesta, P., \& Sefcik, S. (2004). Earnings Management, Stock Issues, and Shareholder Lawsuits. Journal of Financial Economics 71, 27-49.

Eisenberg, T. S., Sundgren, S., \& Wells, M. (1998). Larger board size and decreasing firm value in small firms. Journal of Financial Economics, 48, 35-54.

Erickson, M., Hanlon, M., \& Maydew, E.L. (2006). Is there a link between executive equity incentives and accounting manipulations?, Journal of Accounting Research, 44, 113 - 143.

Ewert, R., \&.Wagenhofer, A (2005). Economic effects of tightening accounting standards to restrict earnings management, The Accounting Review, 80, 1101 - 1124 
Greene, W. (2003). Econometric Analysis. 2cd edition. MacMillan publishing company, New York.

Guilford, J.P., \& Fruchter, B. (1973). Fundamental statistics in psychology and education, $5^{\text {th }}$ edition. New York; McGraw-Hill

Hermalin, B. E. (2005). Trends in corporate governance, Journal of Finance, 60, 2351-2384.

Hinz, R. P., McCarthy, D. D., \& Turner, J. A. (1997), Are women conservative investors? gender differences in participant-directed pension investments.in Dans Gordon, O.S, Mitchell, \& Twinney M.M (eds), In positioning pensions for the twenty-first century 91 - 103. Philadelpand, P.A.: University of pensylvania press. www.sagepub.com/.../seasonal.Sep07-Feb08.pdf-united kingdom

Indjejikian, R. (2007). Discussion of accounting information, disclosure and cost of capital. Journal of Accounting Research, 45, 421426.

Isenmila, P.A., \& Afensimi, E. (2012). Earnings management and ownership structure; evidence from nigeria; Research Journal of Finance and Accounting, 3(7) 24-36

Jensen, M. (1993). The modern industrial revolution, exit, and the internal control systems Journal of Finance, 48, $831-840$. http://dx.doi.org/10.2307/2329018

Jensen, M., \& Meckling, W. (2009). Theory of the firm: Managerial behavior, agency costs, and ownership structure. Journal of Financial Economics, 3, 304-360.

Jones, J. (1995). Earnings management during import relief investigation, Journal of Accounting Research, 29, 193-228.

Klein, A. (2002). Audit committee, board of director characteristics and earning management, Journal of Accounting and Economics, 33, 375-400.

Klein, A. (2002). Economic determinants of audit committee independence. The Accounting Review, 77(2), 435-452.

Klenke, K. (2003). Gender influences in decision-making processes in top management teams. Management Decision 41 (10) $1024-$ 1034.

Lee, C. I., Rosenstein, S., Rangan, N., \& Davidson, W. N. (1992). Board composition and shareholder wealth. The case of management buyouts. Financial Management 21:58- 72.,

Lipton, M., \& Lorsch, J. (1992). A modest proposal for improved corporate governance,Business Lawyers, 59, 59-77.

Nelson, M., Elliot, J., \& Tarpley, R. (2002). Evidence from auditors about managers and auditors' earnings management decisions. The Accounting Review, 77, 175-202

Olayinka, M. U. (2012). Earnings management and corporate governance in Nigeria; Research Journal of Finance and Accounting, 3(3) 1-10

Powell, M., \& Ansic, D. (1997). Gender differences in risk behaviour in financial decision-making; an experimental analysis. Journal of Economic Psychology, 18(6), 605-628.

Riley, W.B., \& Chow, K.V. (1992). Asset allocation and individual risk aversion. Financial Analyst Journal, 48, 32-7.

Scott, W.R. (2009). Financial Accounting Theory. 5 edition. publisher: prentice hall; 5 edition (January 31, 2009) | isbn: 0132072866.

Stolowy, H., \& Breton, G. (2004). Accounts manipulation, a literature review and proposed conceptual framework, Review of Accounting and Finance, 3(1), 5-66.

Stulz, R., (1988). Managerial control of voting rights: Financing policies and the market for corporate control, Journal of Financial Economics, 20: 25-54.

Teoh, S.H., Welch, I., \& Wong, T.J. (1998b). Earnings management and the long-run market performance of initial public offerings, Journal of Finance, 53, 1935-1974.

Trinidad, C., \& Normore, H. (2005). Leadership and gender a dangerous liaison? Leadership \& Organization Development Journal, 26 (7), 574-590.

Westphal, J.D. and Zajac, E.J.(1997), Directors-of-corporation; corporate governance; chief-executive-officers; social - exchange. Administrative science quarter, 42, 161-183.

Yamane, T. (1967). Elementary Sampling Theory. Englewood Cliffs, N.J. prentice-hill, Inc. 